\title{
The Indigent Defendant's Toolbox: Debating the Addition of the Battered Woman Syndrome Expert
}

\author{
Laura D. Warren $\dagger$
}

Law addresses itself to actualities .... Of course a State need not equalize economic conditions. A man of means may be able to afford the retention of an expensive, able counsel not within reach of a poor man's purse. Those are contingencies of life which are hardly within the power, let alone the duty, of a State to correct or cushion.'

\section{- Justice Felix Frankfurter}

Scholars have long debated the role of poverty in the receipt of justice. $^{2}$ Courts have similarly wrestled with adjudication involving destitute legal actors, beginning as early as 1959. In Burns v Ohio, the Supreme Court ruled that indigent defendants had the right to file notice of appeal without first paying a fee. ${ }^{4}$ Burns sparked an entire progeny of cases surrounding indigent defendants' access to legal tools; courts soon added to the state-subsidized list rights including: (a) a trial transcript for use in appeal, (b) assistance of counsel at trial; ${ }^{6}$ (c) assistance of counsel on first direct appeal; ${ }^{7}$ and (d) effectiveness of counsel at both trial and appellate levels.

While states are not required to provide all the assistance that a wealthy litigant may purchase," the government is responsible for providing "meaningful access to justice," which "requires the basic tools of an adequate defense and appeal." 10 But what constitutes a basic legal tool? In 1985, the Court included among such tools the right to a competent psychiatric expert when a defendant's sanity is in ques-

B.A. 1998, Illinois Wesleyan University; J.D. Candidate 2003, The University of Chicago. Griffin v lllinois, 351 US 12, 23 (1956) (Frankfurter concurring).

2 Anatole France aptly noted, "The law, in its majestic equality, forbids the rich as well as the poor to sleep under bridges." Anatole France, The Red Lily 75 (Modern Library 1917).

3360 US 252 (1959).

4 See id at 257.

5 See Griffin, 351 US at 19.

6 See Gideon v Wainwright, 372 US 335, 342-46 (1963).

7 See Douglas v California, 372 US 353,358-59 (1963).

8 See McMann v Richardson, 397 US 759, 771 n 14 (1970).

9 See Ross y Moffitt, 417 US 600, 612 (1974) (noting that the Fourteenth Amendment does not require states to equalize economic conditions).

10 Britt v North Carolina, 404 US 226, 227 (1971). 
tion." Ake v Oklahoma ${ }^{12}$ catalyzed academic commentary; ${ }^{13}$ scholars asked whether such a right extended to any questioning of mental state, such as intent, or was limited exclusively to sanity issues.

Building on the Ake foundation, this Comment asks whether an indigent defendant is entitled to a state-funded battered woman syndrome expert. Guided by $A k e$ 's balancing test and identifiable factors, this Comment answers in the affirmative. Part I explains fundamental background issues, including (A) the $A k e$ decision (which provides the legal foundation for the issue at hand) and (B) the psychological theory of battered woman syndrome. Part II details how courts and academics have approached the theory and its legal applications; this Part explores both statistical patterns and conceptual divisions of case outcomes. Finally, Part III proposes that states fund battered woman syndrome expert testimony for indigent defendants whenever mental state is in question.

\section{FOUNDATIONAL PRINCIPLES: $A K E V$ OKLAHOMA AND BATTERED WOMAN SYNDROME THEORY}

An examination of whether indigent defendants are entitled to a state-provided battered woman syndrome (BWS) expert ${ }^{14}$ requires a review of relevant judicial and psychological background. To question the boundaries of $A k e$, one must know its basic contours; thus, Part I.A begins with a detailed review of $A k e$ and its reasoning. After outlining the case facts, this Part articulates the two key decisional approaches of the Ake Court: (1) the balancing test and (2) relevant factors.

Part I.B then adds psychological theory to this judicial background with a review of battered woman syndrome. This Part intro-

11 See Ake v Oklahoma, 470 US 68, 83 (1985).

12470 US 68 (1985).

13 See, for example, David A. Harris, Ake Revisited: Expert Psychiatric Witnesses Remain Beyond Reach for the Indigent, 68 NC L Rev 763, 764 (1990) (arguing that an appropriate interpretation of $A k e$ must employ a standard based on reasonableness and allow the indigent defendant some measure of participation in the choice of expert); Mark P. Goodman, Note, The Right to a Partisan Psychiatric Expert: Might Indigency Preclude Insanity?, 61 NYU L Rev 703, 706 (1986) (concluding that the $A k e$ analysis implicitly granted indigents the right to a partisan psychiatrist); John M. West, Note, Expert Services and the Indigent Criminal Defendant: The Constitutional Mandate of Ake v. Oklahoma, 84 Mich L Rev 1326,1345 (1986) (arguing that the right to expert assistance under Ake should extend as far as the right to counsel); The Supreme Court, 1984 Term: I. Constitutional Law, 99 Harv L Rev 120, 137 (1985) (suggesting that expert testimony will be crucial and thus required for indigents under $A k e$ whenever a defense is novel or not understood by the lay population).

14 As I use the term throughout the Comment, "battered woman syndrome expert" connotes a general psychiatrist capable of BWS examination and diagnosis, in contrast to one who specializes in the syndrome. For an analysis concluding that this is the minimal, and appropriate, scope of the Ake decision, see text accompanying notes 170-73. 
duces three distinct phases accompanying most abusive relationships and explains their influence upon victim characteristics. The Part concludes by explaining how BWS theory is used to support a battered woman's legal claim of self-defense.

\section{A. Psychiatric Expert Foundation: Ake v Oklahoma}

Glen Burton Ake was arrested in late 1979 and charged with murdering a couple and wounding their two children. ${ }^{15}$ Based on several incidents in jail and Ake's "bizarre" behavior at arraignment, the district court judge ordered that the defendant be examined by a psychiatrist. ${ }^{16}$ The examining psychiatrist diagnosed Ake as a probable paranoid schizophrenic and recommended prolonged psychiatric evaluation; ${ }^{17}$ Ake was committed to a state hospital and declared incompetent to stand trial. ${ }^{18}$ However, state proceedings quickly resumed after hospital psychiatrists placed Ake on medication and reclassified him as competent. ${ }^{19}$

At pretrial conference, Ake's attorney announced that the defendant would raise an insanity defense and requested that the court provide psychiatric evaluation for the indigent defendant; ${ }^{20}$ the court denied the motion. ${ }^{21}$ Ake was then tried for two counts of murder with the sole defense of insanity. During trial, defense counsel questioned hospital psychiatrists, but none were able to testify about his mental state at the time of the alleged crime. ${ }^{22}$ Ultimately, there was no expert testimony for either the prosecution or defense as to Ake's mental state at the time of the offense, and Ake was convicted on all counts. At sentencing, the state asked for the death penalty, relying upon the hospital psychiatrists' testimony to establish that Ake would be dangerous in the future. ${ }^{23}$ Ake presented no expert witnesses to rebut this testimony or to provide evidence in mitigation of punishment; ${ }^{24}$ he was subsequently sentenced to death on each of the murder counts.

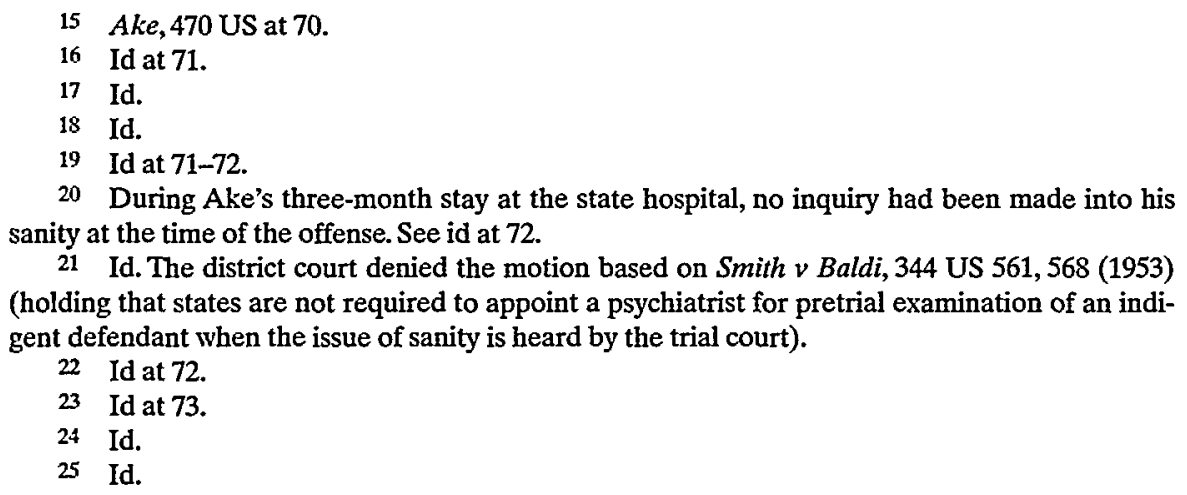

21 Id. The district court denied the motion based on Smith $v$ Baldi, 344 US 561, 568 (1953) (holding that states are not required to appoint a psychiatrist for pretrial examination of an indigent defendant when the issue of sanity is heard by the trial court).

22 Id at 72.

23 Id at 73.

24 Id.

25 Id. 
In reversing these convictions, the Supreme Court emphasized the state's responsibility to provide "meaningful access to justice" to indigent defendants. ${ }^{26}$ The Court discussed when, and under what conditions, psychiatric participation in defense preparation is important enough to require state funding. ${ }^{27}$ The Court resolved this issue for both the trial and sentencing phases through the use of (1) an explicit balancing test and (2) additional relevant factors of consideration. The Court utilized the balancing test to first determine whether the right existed in principle; it then applied the additional factors to determine whether Ake specifically could claim this right. ${ }^{23}$

1. Ake balancing test.

In order to examine when psychiatric expertise is necessary to defense preparation, the Court utilized the balancing test of Mathews $v$ Eldridge $e^{20}$ to determine the state's obligation under the Due Process Clause. The test weighs the following three factors: (1) the nature of the private interest that will be affected by the action of the state; (2) the governmental interest that will be affected if the safeguard is to be provided; and (3) the probable value of the additional or substitute procedural safeguard sought and the risk of an erroneous deprivation of the affected interest if such a safeguard is not provided. ${ }^{30}$

The Court first applied the test to the issue of Ake's sanity at the time the crime was committed. Examining the private interest of the defendant, the Court emphasized the obvious and weighty concern of erroneous conviction: "The private interest in the accuracy of a criminal proceeding that places an individual's life or liberty at risk is almost uniquely compelling. Indeed, the host of safeguards fashioned by

26 Id at 77. The Court cited a string of cases establishing that states must assure a defendant fair opportunity to present a defense, see id at 76, including Griffin v Illinois, 351 US 12 (1956) (holding states must provide a trial transcript to indigent criminal defendants if necessary to a decision on the merits of an appeal); Burns v Ohio, 360 US 252 (1959) (waiving an appeal filing fee for indigent defendants); Gideon $v$ Wainwright, 372 US 335 (1963) (entitling an indigent defendant to the assistance of counsel at trial); Douglas v California, 372 US 353 (1963) (entitling an indigent defendant to counsel on her first direct appeal); Little $v$ Streater, 452 US 1 (1981) (providing an indigent defendant in a paternity action with blood-grouping tests).

27 See $A k e, 470$ US at 77.

28 See id.

29424 US 319, 355 (1976). Although Mathews was a civil case, its test has been employed in criminal contexts as well. See, for example, Schall v Martin, 467 US 253, 263 (1984) (upholding the pretrial detention of juveniles on finding a willingness to commit subsequent crimes); Hewitt $v$ Helms, 459 US 460, 473 (1983) (denying a prisoner's request for a hearing before being placed in administrative segregation).

30 See $A k e, 470$ US at 77 . For further discussion of this balancing test, see text accompanying notes $44-49$. 
this Court over the years to diminish the risk of erroneous conviction stands as a testament to that concern., ${ }^{, 31}$

The Court was not persuaded that the relevant state interests were similarly significant. While recognizing a state interest in economy of judicial process, Ake concluded that minimal financial burdens would be imposed if the right were limited to a single psychiatrist, as already available in many state and government prosecutions. ${ }^{32}$ The Court additionally noted that any state interest in prevailing at trial is tempered by the interests of fair and accurate adjudication, ultimately rendering the government interest in denying psychiatric assistance "not substantial."."

Inquiring into the probable value of psychiatric assistance and risk of error in its absence, the Court endorsed the role of psychiatrists in criminal proceedings. ${ }^{34}$ Again referencing state and federal practices of psychiatric provision, ${ }^{35}$ the Court explained that the psychiatrist's "pivotal" role enables a jury to reach the "most accurate determination of truth." Able to gather facts, interview, analyze, draw conclusions, and offer opinions, psychiatrists can (a) know the probative questions to ask of the opposing party's psychiatrists and how to interpret their responses; (b) identify symptoms of insanity that elude the layperson; and (c) translate medical diagnoses into language with meaning for the trier of fact. ${ }^{37}$ Careful to neither "approve nor disapprove [of] widespread reliance on psychiatrists," the Court instead recognized a substantial probable value in the use of psychiatric assistance in light of evolving practice. ${ }^{3.5}$ The Court concluded that the ab-

31 Ake, 470 US at 78 . This list of safeguards includes those outlined in note 26.

32 See id at 79 ("More than 40 States, as well as the Federal Government, have decided either through legislation or judicial decision that indigent defendants are entitled, under certain circumstances, to the assistance of a psychiatrist's expertise.").

33 Id at 78 .

34 See id at 79-81, 84 ("[In some cases] a defense may be devastated by the absence of a psychiatric examination and testimony; with such assistance, the defendant might have a reasonable chance of success.").

35 See id at 79. See also id at $\$ 2$ n 8 , quoting Irving Goldstein and Fred Lane, Goldstein Trial Techniques $\$ 14.01$ (Callaghan 2d ed 1969) ("Modern civilization, with its complexities of business, science, and the professions, has made expert and opinion evidence a necessity.").

36 Id at 79,81 .

37 See id at 81. For a discussion of the role of psychiatrists in presenting expert evidence, see Peter R. Dahl, Comment, Legal and Psychiatric Concepts and the Use of Psychiatric Evidence in Criminal Trials, 73 Cal L Rev 411, 419-39 (1985) (outlining the uses of psychiatric knowledge within the law); Joel F. Henning, The Psychiatrist in the Legal Process, in Lawrence Z. Freedman, ed, By Reason of Insanity: Essays on Psychiatry and the Law 217, 219-20 (Scholarly Resources 1983) (discussing the growing role of psychiatric witnesses as a result of changing definitions of legal insanity and increased judicial and legislative acceptance of the practice).

38 See $A k e, 470$ US at $81-82$. 
sence of psychiatric assistance would create an "extremely high" risk of inaccurate resolution. ${ }^{39}$

The Court qualified its conclusion, however, by finding it "unlikely" that psychiatric assistance would be of probable value if a defendant's mental condition is not an issue. ${ }^{40}$ The Court elaborated:

The risk of error from denial of such assistance is most predictably at its height when the defendant's mental condition is seriously in question. When the defendant is able to make an ex parte threshold showing to the trial court that his sanity is likely to be a significant factor in his defense, the need for the assistance of a psychiatrist is readily apparent. ${ }^{41}$

When sanity is a factor in the defense, the Court concluded that states must assure an indigent defendant access to a psychiatrist for examination and "assistance in evaluation, preparation, and presentation of the defense." ${ }^{42}$ The Court left states to implement the right on their own terms, denying that defendants have the right to choose their own psychiatrist or receive funds to hire the same. ${ }^{43}$

The Court concluded that the balancing test weighed in favor of providing psychiatric assistance for indigent defendants such as Ake during trial. ${ }^{4}$ The Court similarly determined that the right to psychiatric assistance extends to capital sentencing proceedings when a defendant's future dangerousness is at issue. ${ }^{45}$ Recall that Ake presented no psychiatric experts to rebut the state's psychiatric testimony establishing his future dangerousness; ${ }^{46}$ applying the Mathews three-prong balancing test, the Court found this unconstitutional. ${ }^{47}$ The Court recognized both individual and state interests in preventing an erroneous imposition of the death penalty. It noted that the practice of permitting psychiatric testimony on future dangerousness rests on the assumption that the factfinder will hear testimony from both parties. Consequently, the Court believed that any defendant denied such testimony would lose a significant opportunity to raise questions about

39 Id.

40 Id at 82.

41 Id at 82-83.

42 Id at 83.

43 See id:

This is not to say, of course, that the indigent defendant has a constitutional right to choose a psychiatrist of his personal liking or to receive funds to hire his own. Our concern is that the indigent defendant have access to a competent psychiatrist for the purpose we have discussed, and as in the case on provision of counsel we leave to the states the decision on how to implement this right.

44 See id at 84.

45 See id.

46 See id at 73. See text accompanying notes 23-25.

47 See $A k e, 470$ US at 83-84. 
the state's proof of an aggravating factor. ${ }^{45}$ Thus, in the sentencing phase, "where the consequence of error is so great, the relevance of responsive psychiatric testimony so evident, and the burden on the State so slim," due process requires access to psychiatric examination, testimony, and assistance in preparation. ${ }^{49}$

\section{Ake's additional relevant factors.}

After establishing that indigent defendants may, in certain circumstances, be entitled to psychiatric assistance, the Court went on to determine that Ake specifically qualified for the provision of psychiatric services. ${ }^{50}$ The Court identified several factors in support of its decision that Ake's mental state at the time of the offense was in fact a substantial factor in his defense." Relevant factors included the following: (a) Ake's sole defense was insanity; (b) Ake's behavior was so bizarre that the trial court had ordered a competency examination; (c) the state psychiatrist had found Ake incompetent to stand trial; (d) when Ake was finally declared competent, it was only on the condition of large-dose drug sedation; (e) the examining psychiatrist had described Ake's mental illness as severe; and (f) the state placed the production burden of an insanity defense upon the defendant. ${ }^{52} \mathrm{De}-$ spite these numerous factors, the scope of relevant consideration was left uncertain: "We express no opinion as to whether any of these factors, alone or in combination, is necessary to make this finding., ${ }^{, 53}$

A lone dissent by then Justice Rehnquist contested the Ake majority's conclusions. ${ }^{\text {s. }}$ Justice Rehnquist emphasized the majority's requirement that an indigent defendant make "a preliminary showing that sanity at the time of the offense is likely to be a significant factor at trial" "before receiving a state-appointed psychiatrist. ${ }^{56}$ Questioning whether Ake was truly insane, ${ }^{s 7}$ the dissent insisted that Ake had failed to demonstrate such a "preliminary showing," since the defense introduced no evidence on Ake's mental state during the murders."

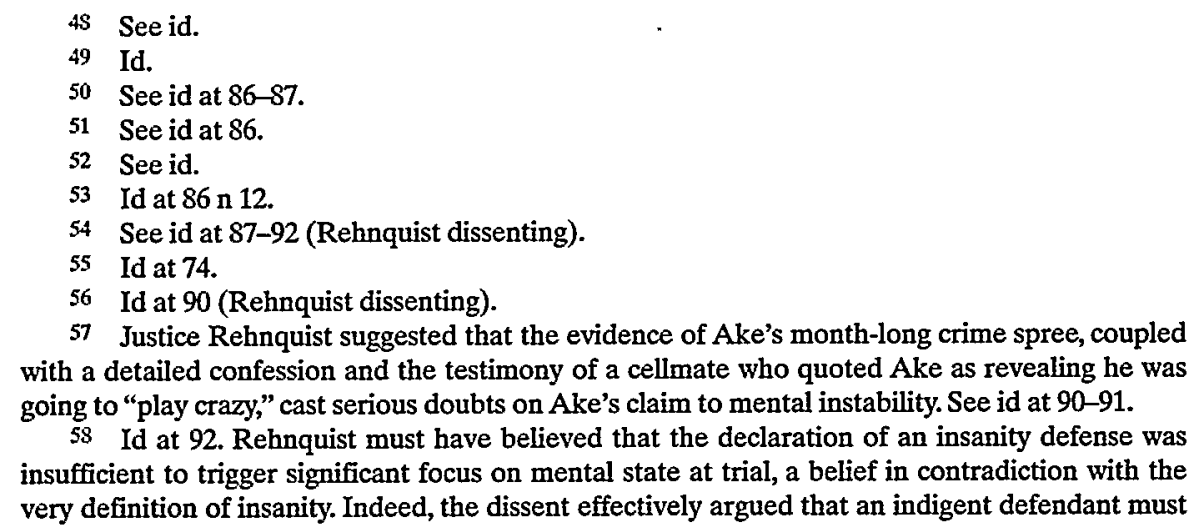

77 Justice Rehnquist suggested that the evidence of Ake's month-long crime spree, coupled with a detailed confession and the testimony of a cellmate who quoted Ake as revealing he was going to "play crazy," cast serious doubts on Ake's claim to mental instability. See id at 90-91.

58 Id at 92. Rehnquist must have believed that the declaration of an insanity defense was insufficient to trigger significant focus on mental state at trial, a belief in contradiction with the very definition of insanity. Indeed, the dissent effectively argued that an indigent defendant must 
Justice Rehnquist further asserted that the majority's creation of a right to psychiatric assistance in defense evaluation, preparation, and presentation impermissibly creates an advocate. ${ }^{59}$ The dissent contended that even assuming the right to a state-appointed psychiatrist existed, the defendant should have access only to a competent opinion, not one that necessarily opposes the views of the prosecution's expert. $^{60}$ "A psychiatrist is not an attorney, whose job it is to advocate."

To Justice Rehnquist's dismay, Ake requires that when a new defendant demonstrates that his or her sanity at the time of the offense is a significant factor at trial, the state must assure the defendant access to a competent psychiatrist who will conduct an appropriate examination and assist in the evaluation, preparation, and presentation of the defense. ${ }^{62}$

\section{B. Battered Woman Syndrome Theory}

Understanding the theory of BWS is crucial to determining whether $A k e$ 's analysis supports extending the indigent expert provision to BWS evidence. This Part presents a detailed review of BWS theory in order to later compare and contrast the role of the BWS expert with that of the psychiatrist supported in $A k e^{63}$

In 1979, Dr. Lenore Walker published The Battered Woman, a groundbreaking book positing the existence of a "battered woman syndrome." ${ }^{s /}$ Walker documented psychological research upon female victims of domestic violence and identified common behavioral patterns exhibited by battered women. In the past two decades, the incorporation of Walker's research into the paradigm of self-defense theory has been both praised and criticized by legal and social science scholars. ${ }^{65}$ Because victims of BWS who assault their batterers tend to

prove he is insane before he can get a psychiatrist to tell him so.

59 See id.

60 See id.

61 Id. This argument is addressed further in Part III.C in the specific context of BWS. See text accompanying notes $170-73$.

62 See $A k e, 470$ US at 83.

63 See Part III.

64 See Lenore E. Walker, The Battered Woman (Harper 1979).

65 Compare Julie Blackman, Potential Uses for Expert Testimony: Ideas Toward the Representation of Battered Women Who Kill, 9 Women's Rts L Rep 227, 231 (1986) (supporting BWS evidence as an "alternative form of reasonableness" that includes more relevant situational factors), with Marilyn McMahon, Battered Women and Bad Science: The Limited Validity and Utility of Battered Woman Syndrome, 6 Psychiatry, Psych, \& L 23, 23-49 (1999) (identifying methodological deficiencies in key empirical studies on which the syndrome is based), David L. Faigman and Amy J. Wright, The Battered Woman Syndrome in the Age of Science, 39 Ariz L Rev 67, 68 (1997) (criticizing judicial acceptance of the theory without further empirical foundation), and Donald A. Downs, More Than Victims: Battered Women, The Syndrome Society, and the Law 138- 
do so during nonconfrontational moments, they have a difficult time meeting the legal requirements of the self-defense doctrine, which focuses on the necessity of proportional force in response to imminent harm. ${ }^{\text {s }}$ BWS can illuminate how a victim might perceive these requirements, even when not under immediate attack due to (1) the battering cycle and (2) learned helplessness.

\section{The battering cycle.}

According to the theory of battered woman syndrome, three distinct phases typify most battering relationships. ${ }^{67}$ The relationship begins in a "tension building" phase, marked by verbal bickering and increasing tension between partners. Soon the relationship erupts into an "acute battering incident" in which the batterer explodes into uncontrollable and violent rage, harming the relationship partner. Finally, the couple enters the "loving contrition" stage, in which the batterer expresses complete regret, continually apologizes, and promises to change his or her future behavior. ${ }^{6 s}$ These three steps repeat each other, forming a cycle of violence in which the victim is reduced to a constant state of fear and anxiety identified as "cumulative terror."

Within the legal context, the cycle theory addresses two components of successful self-defense claims when a battered woman harms her abuser:" (1) fear of imminent harm ${ }^{71}$ and (2) proportional response to harm. ${ }^{n}$ The defendant's knowledge of the aggressor's history, cou-

82 (Chicago 1996) (concluding that "the syndrome connection is a problematic way" to accomplish the task of legally recognizing battered women's self-defense claims and exploring specific problems associated with BWS).

66 See Downs, More Than Victims at 3 (cited in note 65):

The law of self-defense is based on a rather strict presence of necessity: it requires that the defender use deadly force only if threat of death or great bodily harm is imminent or presently impending, and that the response be reasonable, apportioned to the extent or quality of the threat.

See also notes 71-72.

67 See Lenore E. Walker, The Battered Woman Syndrome 126-38 (Springer 2d ed 2000). It is worth noting that although Walker's BWS research and theories typically involve a male batterer, theoretically, the syndrome could occur even when the batterer is female.

68 See id at $126-27$.

69 Id.

70 See Faigman and Wright, 39 Ariz L Rev at 73 (cited in note 65). For a useful summary of traditional self-defense doctrines developed to address the issues of BWS theory, see Jeffrey B. Murdoch, Is Imminence Really Necessity? Reconciling Traditional Self-Defense Doctrine with the Battered Woman Syndrome, 20 N Ill U L Rev 191, 194-98 (2000).

71 See Joshua Dressler, Understanding Criminal Law $\$ 18.01(\mathrm{~B})$ (Mathew Bender 3d ed 2001) ("[D]eadly force is only justified in self-protection if the actor reasonably believes that its use is necessary to prevent imminent and unlawful use of deadly force by the aggressor.") (emphasis omitted).

72 See id at $\$ 18.01$ (D) ("[A] person is not justified in using force that is excessive in reaction to the harm threatened."). 
pled with her physical inability to protect herself, explain how a battered woman could feel imminent harm even when her abuser is not attacking her. These factors may suggest to a trier of fact how a reasonable person in the defendant's position might have perceived a necessity to fight back, because she perceived imminent harm, even though those not experiencing BWS would not. ${ }^{3}$ In suggesting constant fear of serious harm, the cycle theory also accounts for why a serious (and potentially deadly) response is proportional to the threat of harm.

\section{Victims' learned helplessness.}

In order to support a self-defense theory, many states require a defendant to retreat from harm if possible. ${ }^{75}$ The cycle theory cannot initially explain why a woman with BWS does not retreat from her abuser. However, Walker offers a theory of "learned helplessness" to explain why battered women do not merely leave the abusive relationship.

The theory of learned helplessness was first developed by psychologist Martin Seligman, who discovered that laboratory dogs exposed to shock "learn" that they are helpless and thus fail to escape even when provided with an opportunity to do so; ${ }^{n}$ Seligman later generalized this phenomenon to depression in humans. As applied to battered women, the theory posits that victims "learn" after repeated abuse that they cannot control nor escape their partner's violence." Walker likened the experience to electric shocks, which reduce the motivation to respond. ${ }^{80}$ This experience, coupled with the batterer's

73 See, for example, Ibn-Tamas v US, 407 A2d 626, 634 (DC 1979) (describing how BWS expert testimony could substantiate imminent harm by explaining the psychological effects of a husband's prolonged physical abuse upon a wife's perception of danger); People $v$ Wilson, 194 Mich App 599, 487 NW2d 822, 824 (1992) (permitting BWS expert testimony to explain how the battered spouse reacts to the batterer, including the reasonableness of the battered spouse's perception that danger or great bodily harm is imminent).

74 See Faigman and Wright, 39 Ariz L Rev at 73 (cited in note 65). See, for example, Lumpkin v Ray, 977 F2d 508, 509 (10th Cir 1992) (discussing the relevance of proportionality when the batterer is larger than his victim). See also Holly Maguigan, Battered Women and SelfDefense: Myths and Misconceptions in Current Reform Proposals, 140 U Pa L Rev 379, 392 n 34, 419 (1991).

75 See Dressler, Understanding Criminal Law at $\$ 18.02(\mathrm{C})(2)$ (cited in note 71) ("If a person can safely retreat and, therefore, avoid killing the aggressor, deadly force is unnecessary.").

76 See Walker, Battered Woman Syndrome at 116-17 (cited in note 67).

77 See generally Martin E.P. Seligman, et al, Alleviation of Learned Helplessness in the Dog, 73 J Abnormal Psych 256 (1968).

78 See generally Martin E.P. Seligman, Helplessness: On Depression, Development, and Death (W.H. Freeman 1975).

79 See Walker, Battered Woman Syndrome at 116-18 (cited in note 67) (discussing the theory, research, and criticisms of learned helplessness).

80 See id at 118. 
profuse apologies and repeated promises to change during the loving contrition phase, explains why a victim remains in the relationship. In legal terms, learned helplessness shows why the BWS victim does not retreat from the threat of harm as could be required by state law. ${ }^{81}$

In summary, the battered woman syndrome derives from a threestage cyclic relationship of (a) tension building, (b) acute battering, and (c) loving contrition that creates in the victim a hyper-vigilant, continuous fear and negates the motivation to leave the abusive relationship.

\section{LEGAL APPLICATIONS OF BATTERED WOMAN SYNDROME EVIDENCE}

Combining the Ake decision and BWS psychological theory, this Part examines how the two have interacted in actual cases. Courts were initially reluctant to accept expert testimony on $\mathrm{BWS}^{\mathrm{s}}$ based on prominent criticisms of the theory's empirical foundations. ${ }^{83}$ However, the most recent analysis of the issue suggests that such testimony has been admitted as evidence to some degree in all fifty states. ${ }^{24}$ Part II.A details the role BWS evidence has played in legal proceedings and includes statistics on presentation frequency across states and criminal

81 See Dunn v Roberts, 963 F2d 308,313-14 (10th Cir 1992) (permitting use of BWS expert testimony to explain why a defendant suffering from BWS would not leave her batterer); State $v$ Hodges, 716 P2d 563, 567 (Kan 1986):

Expert testimony on the battered woman syndrome would help dispel the ordinary lay person's perception that a woman in a battering relationship is free to leave at any time. The expert evidence would counter any "common sense" conclusions by the jury that if the beatings were really that bad the women would've left her husband much earlier.

82 The first case to admit evidence of BWS was Ibn-Tamas $v$ United States, 497 A2d 626 (DC 1979). The District of Columbia Court of Appeals recognized that BWS could assist the trier of fact in judging the self-defense claim of a battered woman who shot her husband. See id at 635. For a historical review of judicial acceptance of BWS evidence, see Downs, More Than Victims at 77-80 (cited in note 65). See also Cynthia L. Coffee, Note, $A$ Trend Emerges: $A$ State Survey on the Admissibility of Expert Testimony Concerning the Battered Woman Syndrome, $25 \mathrm{~J}$ Fam L 373 (1986-87) (discussing states admitting versus not admitting BWS evidence).

83 See note 65.

84 See Janet Parrish, Trend Analysis: Expert Testimony on Battering and its Effects in Criminal Cases, 11 Wis Women's L J 75, 83 (1996). See also National Institute of Justice, The Validity and Use of Evidence Concerning Battering and Its Effects in Criminal Trials: Report Responding to Section 40507 of the Violence Against Women Act, NCJ 160972 (May 1996), cited in Clare Dalton and Elizabeth Schneider, Battered Women and the Law 746 (Foundation 2001) (concluding the same, and that almost 70 percent of states have found generic BWS expert testimony admissible in order to explain battering and its effects generally). Within federal courts, expert testimony on battered woman syndrome has been admitted under the Criminal Justice Act of 1964, 18 USC \& 3006A(e)(1) (1982), permitting courts to authorize necessary "investigative, expert, or other services necessary for an adequate defense" where defendants are financially unable to pay for them. State courts have admitted such testimony under similar state statutes authorizing expert assistance to indigent defendants. See Parrish, 11 Wis Women's L J at 83. 
categories. Part II.B then examines specific controversies involving indigent defendants and BWS expert testimony.

\section{A. Empirical Development of BWS Evidence}

Battered woman syndrome has been identified as "an enormously elastic concept that can cover a wide variety of difficult cases" $^{\text {"85 }}$ and, as such, has been utilized across numerous criminal and civil contexts. BWS is most readily accepted in cases in which the victim attacks or kills her abuser and asserts self-defense. As of 1996, 96 percent of states permit BWS testimony in fact patterns in which the victim killed in response to an advancing abuser, while 30 percent of states admitted such testimony where a battered woman killed a sleeping abuser. ${ }^{85}$ Battered woman syndrome testimony has been allowed in other criminal contexts as well, including as support for and against arguments of diminished capacity/lack of intent; ${ }^{87}$ duress; ${ }^{28}$ child abuse; ${ }^{89}$ sentencing; ${ }^{90}$ and credibility. Within civil contexts, BWS testimony has been utilized in at least 20 percent of states, in cases involving family law, divorce, and custodial rights issues.

85 Faigman and Wright, 39 Ariz L Rev at 104 (cited in note 65).

86 Parrish, 11 Wis Women's L J at 105 (cited in note 84). Compare Dalton and Schneider, Battered Women and the Law at 746 (cited in note 84) (concluding as of 1995 that nearly 70 percent of courts find BWS expert testimony relevant to a self-defense claim). For a voluminous list of states and cases accepting BWS testimony for self-defense justification, see Parrish, 11 Wis Women's L J at 104-05 n 47, $130 \mathrm{n} 172$ (cited in note 84).

87 Thirty percent of states have permitted BWS within this context. Dalton and Schneider, Battered Women and the Law at 746 (cited in note 84); Parrish, 11 Wis Women's L J at $124 \mathrm{n} 131$ (cited in note 84).

88 Sixteen percent of states have allowed BWS evidence to support arguments of duress, while 10 percent of states have refused. Parrish, 11 Wis Women's L J at $109 \mathrm{nn} 61-62$ (cited in note 84). Compare Dalton and Schneider, Battered Women and the Law at 746 (cited in note 84) (concluding that two-thirds of states permit BWS testimony concerning acts performed under duress).

89 Courts in at least three states (Nebraska, New York, and West Virginia) have discussed BWS and its influence upon the mother's failure to take protective action; more have precluded the use of expert testimony for this purpose. See Parrish, 11 Wis Women's L J at 123 nn 128-29 (cited in note 84).

90 Twenty percent of states permit BWS testimony to demonstrate the existence of mitigating factors in sentencing. See Dalton and Schneider, Battered Women and the Law at 746 (cited in note 84); See Parrish, 11 Wis Women's L J at 125 n 140,130 n 180 (cited in note 84).

91 Approximately 25 percent of states accept BWS testimony to support credibility. Parrish, 11 Wis Women's L J at 124-25 n 136, $130 \mathrm{n} 176$ (cited in note 84). See also Dalton and Schneider, Battered Women and the Law at 746 (cited in note 84).

92 Parrish, 11 Wis Women's L J at $110 \mathrm{n} 66$ (cited in note 84).

93 Only a few states have explicitly found BWS expert testimony relevant to these issues. See id at 123 n 129,126 n 145. 


\section{B. Common Law Treatment of BWS Experts in Indigent Contexts}

Few courts have addressed, much less agreed, whether Ake requires state funding of battered woman syndrome expert testimony. Courts that have split on the issue have at least taken similar approaches to the analysis. For example, the mental context to be addressed by the BWS testimony is relevant to the case outcome. In addition, the presence or absence of a defendant competency examination and the source of the expert's appointment also influence the decision.

1. Context of mental state addressed by BWS expert testimony.

In all cases to date that addressed whether Ake accords an indigent the right to BWS experts, the defendants stood accused of homicide. The courts were amenable to state provision of an expert where the defense sought BWS testimony regarding the mental state of the defendant at the time of the crime, which would nullify the criminal intent necessary for homicide.

In People v Evans, ${ }^{95}$ an Illinois appellate court focusing on criminal intent concluded that a BWS expert is a "necessary expert witness" and mandated state funding for an indigent who shot her abusive husband as he approached her. The Evans court required a demonstration that (a) expert services were necessary to prove a "crucial issue" in the case and (b) lack of funds would prejudice the defendant." In Evans, the court declared that BWS testimony was necessary to establish the crucial issue of state of mind at the time of the killing." The court emphasized that the testimony could not only determine the scope of culpability (self-defense versus murder versus involuntary manslaughter) but could also explain why the defendant might fear imminent harm from the approach of an unarmed man."

94 See Dunn v Roberts, 963 F2d 308, 314 (10th Cir 1992) (ordering a new trial for a woman convicted of aiding and abetting multiple murders committed by her abusive boyfriend); State $v$ Dannels, 226 Mont 80, 734 P2d 188, 197 (1987) (affirming the defendant's deliberate homicide conviction for a hired hit on her husband); Ledford $v$ State, $254 \mathrm{Ga} 656,333$ SE2d 576, 577 (1986) (affirming a murder conviction of wife who shot and burned her abusive spouse); People $v$ Evans, 271 Ill App 3d 495, 648 NE2d 964, 971 (1995) (reversing a conviction of voluntary manslaughter for a woman who shot her approaching husband); State v Aucoin, 756 SW2d 705, 716 (Tenn Crim App 1988) (affirming the defendant's conviction for first-degree murder for shooting her batterer as he slept).

95271 Ill App 3d 495, 648 NE2d 964 (1995).

96 Id at 968-69.

97 Id.

98 See id at 969 . The court did not identify what specific state of mind would be necessary.

99 See id (explaining that BWS testimony would be crucial to showing that the approach of defendant's unarmed husband could justifiably elicit a lethal response from her based upon their history). 
Evans identified the "crucial" issue of homicidal intent as the factor requiring indigent access to BWS testimony. ${ }^{100}$ Two other state courts also relied on similar reasoning to deny the requested funds. In Ledford $v$ State, ${ }^{101}$ the Supreme Court of Georgia affirmed a lower court refusal to grant funds to an indigent defendant for BWS testimony. ${ }^{102}$ The defendant admitted to killing and burning her batterer, as well as staging a burglary after the murder to evade suspicion. ${ }^{103}$ At trial, the defendant sought provision of an expert to testify specifically on BWS; the district judge instead ordered her examined for competency and degree of criminal responsibility. ${ }^{104}$ On appeal, Georgia's highest court affirmed the judge's refusal to grant the defendant funds for further psychiatric evaluation, reasoning that this initial psychiatric examination was sufficient to cover the issue of intent: "[The trial court's] order contemplates an examination that could relate to battered women's syndrome." peals used similar reasoning in State $v$ Aucoin. ${ }^{106}$ While awaiting pretrial proceedings for killing her batterer, Aucoin was examined by a clinical psychologist and gave notice that she would assert the insanity defense. ${ }^{107}$ Defense counsel requested funds to hire a private BWS expert for further explanation, refusing the district attorney's offer to utilize a court-appointed doctor. ${ }^{108}$ The district judge denied Aucoin's request, and the appellate court affirmed. ${ }^{109}$ The court emphasized that the defendant was not entitled to choose her own psychiatrist and had failed to take advantage of the court-appointed expert offered to her. ${ }^{110}$ Further, the court did not believe defendant's case was prejudiced, because the original clinical psychologist had eventually testified on behalf of the defendant."1

State provision of BWS expert testimony has also been endorsed to address the question of intent in a compulsion defense to a charge of homicide. ${ }^{112}$ In the only federal case to address the issue of BWS ex-

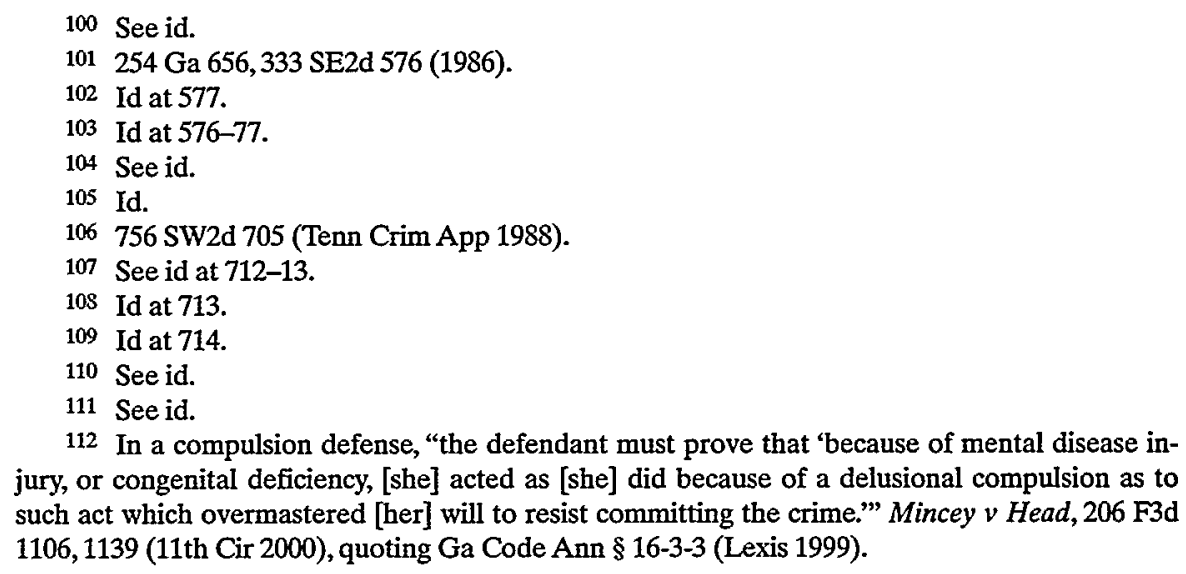

112 In a compulsion defense, "the defendant must prove that "because of mental disease injury, or congenital deficiency, [she] acted as [she] did because of a delusional compulsion as to such act which overmastered [her] will to resist committing the crime." Mincey $v$ Head, 206 F3d 1106,1139 (11th Cir 2000), quoting Ga Code Ann $\$ 16-3-3$ (Lexis 1999). 
pert assistance under Ake, the Tenth Circuit in Dunn $v$ Roberts ${ }^{113}$ supported government funding of testimony for a woman prosecuted as an accomplice to her boyfriend's crimes. The court affirmed a federal district court order providing a BWS expert to testify to the necessary mental state for a compulsion defense. ${ }^{14}$ Despite the fact that the defendant had not raised the issues of competence or insanity, the Tenth Circuit concluded that state-funded BWS testimony was mandated because it would be significant in rebutting the requisite intent for aiding and abetting. ${ }^{115}$ The state's aiding and abetting theory required it to prove beyond a reasonable doubt that the defendant specifically intended to assist her boyfriend in committing crimes. ${ }^{116}$ The state thus asked the jury to infer the defendant's specific intent from her continued presence with her boyfriend throughout his crime spree. ${ }^{117}$ BWS expert testimony was therefore relevant because it could provide an alternative reason for the woman's continued presence (learned helplessness), which involved no such intent."

Courts appear unwilling to extend state provision of BWS testimony to a defendant seeking to bolster her credibility. In State $v$ Dannels, ${ }^{119}$ the defendant was in a hotel room with her allegedly abusive husband when someone broke into the room and killed him. The subsequent crime investigation suggested that the defendant had hired the killer and assisted in staging the robbery. ${ }^{120}$ During questioning, the defendant claimed that bruises found in a medical examination were inflicted during the robbery; in fact, the bruises were too old to be the result of the crime. ${ }^{121}$ Prior to trial, defense counsel requested funds for a BWS expert who could explain why a battered woman would lie about the source of her injuries; ${ }^{12}$ the request was denied. ${ }^{123}$ The Montana Supreme Court affirmed, concluding that funds for BWS expertise are not accessible where the testimony is to be used to bolster credibility (to show why the defendant lied).

113963 F2d 308 (10th Cir 1992).

114 See id at 313.

115 See id.

116 See id, quoting State v McDaniel, 228 Kan 172, 612 P2d 1231, 1238 (1980) ("Mere association ... or mere presence in the vicinity of the crime is insufficient to establish guilt as an aider and abettor.").

117 See Dunn, 963 F2d at 313.

118 See id at 313-14 (suggesting that such evidence could solve the "mystery" of why the defendant remained despite repeated abuse).

119226 Mont 80, 734 P2d 188 (1987).

120 Id at 191-92.

121 Id at 192.

122 Id.

123 Id.

124 See id at 192-93 ("Defendant did not seek to prove that she suffered from abused spouse syndrome and, as a result, did not have the necessary state of mind to commit the homicide. Rather, defendant planned to use the syndrome as an explanation for the reason she lied ... 
2. Prior examination history and expert appointment.

Another factor considered by at least one court examining an indigent right to BWS expert testimony is the presence of a competency examination. As previously mentioned, Ledford denied further funding for BWS evaluation where the defendant had already received a state-ordered competency examination, concluding this examination was sufficient to provide relevant BWS evaluation and testimony. ${ }^{125}$

One court has suggested that any potential BWS examination, whether limited to purposes of competency or covering a broader psychiatric examination, is confined to court-appointed doctors. ${ }^{125}$ In Aucoin, although the district attorney agreed to an examination by a court-appointed doctor, defense counsel refused and instead insisted that the defendant had a right to independent examination by private doctors of her own choosing. ${ }^{127}$ Rejecting this argument, the Court of Appeals reasoned that the scope of Ake did not extend to a defendant's right to choose his or her own expert: "[A]n accused clearly has no right to a "psychiatric advocate." 25 Rather, the court found that once a defendant has some form of psychiatric assistance, further specialized help is not required. ${ }^{129}$

\section{SOLUTION: THE APPLICATION OF AKETO BWS}

Of these few cases that address state funding of battered woman expert evidence, most converge on the conclusion that indigent defendants have a right to psychiatric assistance in specific situations. However, what is the underlying principle to that right, and consequently, to what extent should such a right, if granted, be limited? As discussed in Part II.B, courts granting indigent access to BWS testimony rely on $A k e$ and its focus on the defendant's mental state. Part III.A applies the $A k e$ balancing test and III.B applies the additional relevant factors to this specific context. After demonstrating that Ake's balancing test and relevant factors support indigent access to BWS experts, Part III.C of the Comment concludes that BWS testimony should be funded for indigent defendants when it is utilized to nullify the mental state of any element of an alleged offense.

\footnotetext{
to buttress her credibility."). The court additionally presented a state statute limiting evidence of mental disease to circumstances where "it is relevant to prove that the defendant did or did not have a state of mind which is an element of the offense." Id at 192.

125 See 333 SE2d at 577. See text accompanying notes 101-05.

126 See Aucoin, 756 SW2d at 713.

127 See id.

$12 S$ Id at 714, quoting Collins v State, 506 SW2d 179, 187 (Tenn Crim App 1973).

129 See Aucion, 756 SW2d at 714.
} 
A. The Ake Balancing Test

As applied to BWS experts, Ake's three-prong balancing test of (1) the private interest; (2) the state interest; and (3) the probable value and risks of the procedural safeguard at issue, supports state funding for indigent defendants. Within all three prongs, the interests and risks involved with the denial of BWS expert funding parallel those of psychiatric funding in Ake.

\section{The individual interest.}

The individual interest involved with BWS funding in the criminal context is equivalent to that recognized in Ake. As Ake concluded, any private interest in criminal proceedings is "obvious and weighs heavily" ${ }^{\text {"130 }}$ for two reasons: (1) the accuracy of criminal proceedings is "uniquely compelling" because it places an individual's life and liberty at risk, ${ }^{131}$ and (2) the many judicial safeguards against an erroneous conviction support this concern. ${ }^{1.2}$ Indeed, the Court has repeatedly held that with a greater magnitude of potential loss, a defendant is entitled to greater due process protections. ${ }^{133}$ Since most BWS experts are summoned in cases of assault or homicide, ${ }^{1,4}$ the accompanying threat of incarceration would represent significant potential loss and, thus, demand the due process protection of a necessary BWS expert.

Even if state funding of BWS expert testimony is not designated a fundamental right of indigent defendants, the fact that the Court supports flexibility and context-specificity of due process rights would permit such funding to be determined on a case-by-case basis. The Court has pronounced:

Asserted denial [of due process] is to be tested by an appraisal of the totality of facts in a given case. That which may, in one setting, constitute a denial of fundamental fairness, shocking to the universal sense of justice, may in other circumstances, and in the light of other considerations, fall short of such denial. ${ }^{1.5}$

130470 US at 78.

131 Id.

132 See id.

133 See, for example, Little $v$ Streater, 452 US 1, 13 (1981) (holding that because of the importance of "familial bonds," procedural due process was required prior to finding such bonds in paternity suits); Goldberg v Kelly, 397 US 254, 262-63 (1970) ("The extent to which procedural due process must be afforded the [defendant] is influenced by the extent to which he may be "condemned to suffer grievous loss."'), quoting Joint Anti-Fascist Refugee Committee v McGrath, 341 US 123, 168 (1951) (Frankfurter concurring).

134 See text accompanying note 86.

135 Gideon $v$ Wainwright, 372 US 335, 339 (1963), quoting Betts v Brady, 316 US 455, 462 (1942) (concluding that the Fourteenth Amendment does not require states to appoint counsel to indigent criminal defendants, a decision later overruled by Gideon). 
Because due process rights are determined by surrounding circumstances, indigent rights to state-funded BWS experts should at least be permissible on a case-by-case basis to address those instances where the individual interests at stake are particularly great, such as proving self-defense to a homicide charge.

\section{The state's interest.}

The state's interest in funding BWS expert testimony is likewise equivalent to that asserted in the criminal context of $A k e$, which similarly does not match the gravity of the individual's interest. ${ }^{135}$ Ake posited that government interest in criminal contexts is "not substantial," in light of compelling interests of both the state and the individual in accurate criminal dispositions. ${ }^{137}$ Such an interest is not apparently limited by the type of expert utilized at trial and thus should extend to the BWS context. In addition, the Ake Court rejected state economic interests as significant where the obligation would be limited to the provision of single psychiatrist; ${ }^{133}$ presumably funding of BWS testimony would be limited to a single expert as well.

In addition to those interests articulated in $A k e$, a state interest in limiting successful due process challenges also weighs in favor of state-funded BWS testimony. Any economic burden of hiring such an expert might be tempered by the removal of the economic costs of remand or a new trial. ${ }^{139}$ The latter costs may be unusually prominent in cases involving battered woman syndrome issues; while only 8.5 percent of homicide appeals result in discharge or new trial, one study suggests that 40 percent of BWS homicide cases have resulted in reversals. ${ }^{140}$ Yet another empirical examination found that among states considering whether trial counsel was ineffective for failing to offer BWS testimony, 40 percent answered in the affirmative. ${ }^{141}$

3. Probable value and risk of erroneous deprivation.

Finally, an examination of $A k e$ 's third factor of probable value and risk of deprivation of BWS testimony reveals strong parallels between BWS and psychiatry that demand state funding. Like psychiatrists, BWS experts are utilized commonly in trials where the psychological issues are relevant: Such testimony has been admitted as evi-

136 See text accompanying notes 32-33.

137470 US at 78-79.

138 See id at 78.

139 See Supreme Court, 99 Harv L Rev at 136 (cited in note 13).

140 Maguigan, 140 U Pa L Rev at 433 (cited in note 74), citing Joy A. Chapper and Roger A. Hansom, Understanding Reversible Error in Criminal Appeals: Final Report 38 (National Center for State Courts 1990).

141 Parrish, 11 Wis Women's L J at 84 (cited in note 84). 
dence in some degree in all 50 states, ${ }^{142}$ and 90 percent of states accept BWS testimony in traditional self-defense homicide cases. ${ }^{1.3} \mathrm{BWS}$ experts can also fulfill functions identical to those stressed by the Ake court as necessitating psychiatric testimony. ${ }^{144}$ The BWS expert would be able to identify symptoms that would "elude lay witnesses," as the hypervigilance, cycles, and learned helplessness of the battered woman as outlined by Walker. ${ }^{146}$ A BWS expert could further "translate" a psychological diagnosis into "language with meaning" for the trier of fact, ${ }^{147}$ connecting syndrome symptoms to legal terminology, such as the "imminent fear" component of self-defense or specific intent.

Just as the Ake court dwelt on the inexactitude of psychiatry and diagnostic disagreements within the profession, BWS carries similar differences and debate. ${ }^{145}$ Indeed, such criticism is crucial to a potential argument against the parallel between psychiatry and BWS: BWS experts might not have a prosecutorial counterpart. In Ake, the Court assumed that psychiatric testimony would be presented by both sides; ${ }^{14 y}$ it emphasized that this battle of experts would lead jurors to the "most accurate determination of truth." ${ }^{150}$ If empirical evidence suggests that BWS experts are not countered by an equivalent prosecutorial witness, this might suggest to the jury that there is only one right answer (as would a single psychiatrist) and would conflict with the Ake Court's conception of why the defense expert is necessary. However, if the prosecution is likely to present an opposing expert, the BWS expert would again parallel the psychiatrist's advantage announced in Ake of knowing the "probative questions" to àsk of the state's expert. ${ }^{\text {ist }}$ Common sense suggests that no prosecutor would permit any expert to testify to such a crucial issue as criminal intent without providing her own opposing witness. ${ }^{152}$ Indeed, with the nu-

142 See id at 83 .

143 Id at 84.

144 As mentioned in Part I.A.1, these functions include psychiatrists' ability to gather facts, interview, analyze, draw conclusions, and offer opinions. In addition, psychiatrists can (a) know the probative questions to ask of the opposing party's psychiatrists and how to interpret their responses; (b) identify symptoms of insanity that elude the layperson; and (c) translate medical diagnosis into language with meaning for the trier of fact. See $A k e, 470$ US at 81 . See text accompanying notes $36-37$.

145 Ake, 470 US at 81.

146 See Walker, Battered Woman Syndrome at 176-77, 126-27, 116-18 (cited in note 67). See Part I.B.

147 Ake, 470 US at $\$ 1$.

148 See note 65.

149 See 470 US at $\$ 4$.

150 Id at 81 .

151 Id.

152 Indeed, a few scholars have suggested ways in which prosecutors may utilize BWS evidence. See generally Paula Finley Mangum, Reconceptualizing Battered Woman Syndrome Evi- 
merous academic critics of the battered woman syndrome itself, ${ }^{153}$ it is highly probable that any opposing witness, even if not trained in BWS specifically, could criticize the scientific methodology of its theoretical conclusions. $^{154}$

\section{B. Application of Ake Factors}

In addition to the balancing test, the Ake Court enumerated factors making it more likely that a specific defendant's mental state is a substantial issue warranting state funding for indigents; ${ }^{15 s}$ some of these factors may be generalized to BWS testimony to determine when state funding is required for a specific defendant. For example, one factor contemplated by the Ake Court was whether insanity (as diagnosed by the psychiatric expert) was the sole defense offered. ${ }^{156}$ Specific to BWS, state funding should be required when the battered woman syndrome is the exclusive defense offered; $;^{157}$ the likelihood of state funding should also increase where BWS evidence is the sole link to self-defense, since this comports with the theme of "crucial" evidence $^{15 s}$ that seems to justify the relevance of this factor. ${ }^{159}$ The state may carry a greater responsibility to fund BWS expert testimony when other psychiatrists have suggested the presence of such a mental state in the defendant. ${ }^{160}$ Finally, jurisdictions should be more willing to provide BWS expert testimony when a defendant carries the burden of production on an issue, ${ }^{161}$ and the testimony is thus more important to a successful defense.

dence: Prosecution Use of Expert Testimony on Battering, 19 BC Third World L J 593 (1999) (exploring ways in which BWS expert testimony can be utilized to prosecute domestic violence); Sarah Crippin Madison, Comment, A Critique and Proposed Solution to the Adverse Examination Problem Raised by Battered Woman Syndrome Testimony in State v. Hennum, 74 Minn L Rev 1023, 1026 (1990) (arguing that BWS expert testimony by the defense should be countered by an adverse examination of a prosecutorial expert).

153 See note 65.

154 See id. The expert would also be free to criticize the case-specific diagnosis of the defendant.

155 See Part I.A.2.

156 See 470 US at 86.

157 See, for example, Aucoin, 756 SW2d at 714 (rejecting defendant's request to obtain a state-funded BWS expert to assist in development of an insanity defense).

158 See Evans, 648 NE2d at 968 (permitting BWS expert testimony "crucial" to demonstrating why the unarmed approach of a batterer could elicit a lethal response from a battered spouse).

159 See note 94 for examples of cases where BWS was the exclusive link to self-defense. See also Maguigan, $140 \mathrm{U} \mathrm{Pa} \mathrm{L} \mathrm{Rev} \mathrm{at} 400$ (cited in note 74).

160 This corresponds with the conclusion of the $A k e$ court that multiple psychiatrists had described his condition as severe, and therefore psychiatric assistance was more likely to be crucial to the defense. See 470 US at 86. For a case example, see Aucoin, 756 SW2d at 712-13 (describing how a court-appointed medical doctor concluded upon examination that defendant had a mental illness).

161 The $A k e$ Court believed that the burden of production upon a defendant pleading insan- 
Even if such factors are not met, either individually or as a group, BWS expert funding still may be permissible based on Ake's own qualifier that it expressed no opinion on whether any factors (individually or in combination) are necessary to require state funding. ${ }^{1.2}$ Indeed, subsequent judicial interpretations of Ake have exclusively utilized its balancing test and ignored these additional factors when considering state responsibility for BWS experts. ${ }^{1.3}$

\section{Scope of Indigent Right to BWS Expert}

Both an analysis of caselaw and Ake's balancing test/relevant factors suggest that defendants are entitled to some form of psychiatric review in which BWS can be examined and/or diagnosed. ${ }^{164}$ Since the Ake Court emphasized the defendant's mental state "at the time of the offense," ${ }^{\prime \prime s}$ state-funded BWS testimony should also focus on the time of the offense. Thus, BWS testimony should be funded to inform fact-finding regarding intent at the time of the crime but denied when utilized to address defendant's mental state at other times. Consequently, claims of self-defense or action under duress would entitle the indigent defendant to a state-sponsored BWS expert, because such claims contest the defendant's mental state at the time of the crime; BWS testimony would inform whether the defendant felt reasonable fear at the time of the crime or whether the defendant's mental state was coercively influenced by another at the time of the offense. For example, both Evans and Dunn funded BWS testimony to establish defendant's state of mind at the time of the offense; ${ }^{166}$ the Evans expert addressed the defendant's intent as a killer, while the Dunn expert examined the defendant's intent as an aider and abettor of the crime of homicide. In addition, both Ledford and Aucoin recognized the ability of BWS testimony to address homicidal intent, although both denied funds based on previous examination opportunities. ${ }^{167}$

In contrast, the use of BWS testimony to establish other states of mind outside of intent at the time of the crime would not be permitted. ${ }^{108}$ For example, utilizing BWS to explain why a defendant has lied in order to bolster credibility impermissibly addresses her mental state

ity also contributed to the necessity of expert services. See 470 US at 86.

162 See id at $86 \mathrm{n} 12$.

163 All of the cases applying the Ake standard to BWS evidence relied solely upon the balancing test. See Part II.B.

164 See Parts III.A and III.B.

165470 US at 83.

166 See Dunn, 963 F2d at 313; Evans, 648 NE2d at 968-69.

167 See Ledford, 333 SE2d at $657 ;$; Aucoin, 756 SW2d at 714.

$16 \mathrm{~S}$ For example, in cases where defendants attempt to establish remorse or credibility, or in family law and divorce contexts, BWS testimony would not be permitted because any intent is unrelated to the time of an offense. 
at the time she lied, rather than at the time of the offense for which she stands accused. BWS testimony was not permitted in Dannels to support credibility that went to the defendant's mental state for a statement made after the crime had occurred. ${ }^{169}$

Prior caselaw also raises the question of whether the provision of a BWS expert requires funding for a general psychiatrist who understands BWS theory, or a specific BWS specialist. ${ }^{170}$ How thorough must the expert's BWS knowledge be to meet the demands of the Ake requirements? Indigent defendants seeking to argue mental state at the time of the offense clearly are entitled at a minimum to a general psychiatrist capable of diagnosing BWS. Both prior caselaw and pragmatic concerns indicate that such a provision is all that is necessary to comport with state responsibilities under $A k e{ }^{171}$ there is no requirement to fund a psychiatrist who specializes in BWS.

In rejecting state funding for BWS expert testimony, Ledford and Aucoin reasoned that an opportunity for examination by a general psychiatrist, able to diagnose BWS, was sufficient expert provision." Any broader right suggests pragmatic difficulties under the $A k e$ analysis: It would be both expensive and difficult to obtain psychiatric experts specializing in the exact form of mental illness from which a defendant claims to suffer. Note that the Court did not provide Ake the right to a psychiatrist specializing in paranoid schizophrenia but merely one capable of rendering such a diagnosis. ${ }^{173}$ Similarly, limiting the provision of a BWS expert to a psychiatrist who endorses the BWS theory and is capable of diagnosing the syndrome sufficiently protects the individual liberty interest, while limiting state labor and financial burdens.

Finally, as was the case in $A k e,^{174}$ states should be able to implement the selection process of providing a BWS expert as they see fit. Any rights in the selection process for BWS experts should not expand beyond those provided in Ake, where the Court denied that defendants had any right to choose a psychiatrist of their personal liking or receive funds to hire the same.

169 See 734 P2d at 193 (refusing to allow BWS testimony to explain her reasons for lying after the crime about the source of a bruise).

170 See, for example, Aucoin, 756 SW2d at 714 (denying defendant a right to an "advocate" after the state offered to provide a court-appointed BWS expert).

171 See $A k e, 470$ US at 83 ("This is not to say ... that the indigent defendant has a constitutional right to choose a psychiatrist of his personal liking or to receive funds to hire his own."). See also text accompanying note 43 .

172 See text accompanying notes 101-11.

173 See $A k e, 470$ US at 83.

174 See id.

175 See text accompanying notes $42-43$. Such a right to choose one's expert was likewise dismissed by the Aucoin court in the BWS context. See Aucoin, 756 SW2d at 713. 


\section{CONCLUSION}

The Supreme Court has determined that government is responsible for providing "meaningful access to justice."116 Just as psychiatric assistance is a "basic tool" to achieving this end, so too must battered woman syndrome experts be added to the toolbox. The application of Ake's balancing and relevant factor tests to BWS defendants demonstrates that expert testimony should be provided. To preserve individual liberty while minimizing state burdens, indigent access to a BWS expert should be limited to testimony regarding defendant's mental state at the time of the crime. The expert should be familiar with, but does not have to specialize in, battered woman syndrome theory. Additionally, states should retain the discretion to select an appropriate expert. While true, as Justice Frankfurter proclaimed, that a state need not equalize economic conditions, ${ }^{178}$ the "actualities" to which the law addresses itself suggest that BWS testimony is a commonly accepted, and often crucial, factor in protecting the individual liberties of domestic abuse victims. Accordingly, the contingencies of life ${ }^{179}$ must not always be mirrored in those of law.

176 Britt v North Carolina, 404 US 226, 227 (1971).

177 See id.

178 See Griffin v Illinois, 351 US 12,23 (1956) (Frankfurter concurring).

179 See id. 


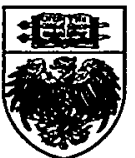

